\title{
A Ten-year Period of Daily Sea Surface Temperature at a Coastal Station in Reunion Island, Indian Ocean (July 1993 - April 2004): Patterns of Variability and Biological Responses
}

\author{
François Conand ${ }^{1}$, Francis Marsac ${ }^{2}$, Emmanuel Tessier ${ }^{1} \&$ Chantal Conand ${ }^{1}$ \\ ${ }^{1}$ University of La Reunion, Marine Ecology Laboratory, Av. René Cassin 97715 St Denis, France; ${ }^{2}$ Institut de \\ Recherche pour le Développement, Centre de Recherche Halieutique Mediterranenne et Tropicale, Av. Jean \\ Monnet, 34023 Sète cedex, France
}

\begin{abstract}
Key words: Sea water temperature increase, ten-year period, Indian Ocean, Reunion Island, coral bleaching, tuna fishery
\end{abstract}

\begin{abstract}
Sea surface temperature (SST) was recorded hourly by an automatic data recorder in Reunion Island, at Pointe des Galets (215 S, $\left.55^{\circ} 17 \mathrm{E}\right)$ during 1993-2004. The data logger was installed on a beacon located at the port entrance exposed to the open sea. The SST measurements associated with auxiliary environmental data, such as wind stress, depict the main patterns of variability at various timescales for the marine climate of Reunion Island. The 'ten-year' annual mean temperature is $25.7^{\circ} \mathrm{C}$ and the annual amplitude is $4.6^{\circ} \mathrm{C}$. The highest monthly means are observed in February and March $\left(28.0^{\circ} \mathrm{C}\right)$ and the lowest occur in September $\left(23.4^{\circ} \mathrm{C}\right)$. The daily variation ranges from 0.25 to $0.74^{\circ} \mathrm{C}$ according to the season. In summer, the tropical cyclones are the major cause of short term variability, with sudden drops of SST than can exceed $2^{\circ} \mathrm{C}$ within a few hours. The annual cycle of SST is closely associated with that of wind stress, with a lagged response of about 2 months of SST to wind forcing. Throughout the 'ten-year period' covered by our dataset, the coldest years were 1993 and 2000, and the warmest were 2003 and 2004. A trend of increasing SST is suggested for the two major seasons, with a magnitude of $0.088^{\circ} \mathrm{C} / \mathrm{yr}$ in summer and $0.052^{\circ} \mathrm{C} / \mathrm{yr}$ in winter. Finally, the SST trend and variability depicted at our sampling site is shown to reflect the SST patterns of the whole south tropical Indian Ocean. Biological responses to SST variability are shown by coral bleaching events and the local tuna fishery. The major coral bleaching events recorded in Reunion in 1998, 2001, 2003 and 2004 occurred during episodes of intense and sustained anomalous high temperatures. The catch per unit effort (CPUE) of the local pelagic fishery was negatively correlated to SST anomalies with a decreasing trend of CPUE observed over the years, accompanied by an overall increase of SST. The SST observations made in Reunion Island, in a largely unsampled region of the Indian Ocean, show their relevance at a larger regional scale and their usefulness in monitoring changes of some biological components of the marine ecosystem. These examples highlight the need to maintain networks of automatic loggers worldwide at coastal stations.
\end{abstract}

\section{INTRODUCTION}

Long-term recording of sea surface temperature (SST) in fixed locations is one of the simplest methods used to observe changes in the marine environment. There are a limited number of so- called "coastal stations" throughout the world where continuous recording of temperature is undertaken. The goal of this article is to provide the scientific community with information on SST patterns and trends, at different time-scales, for the period July 1993-April 2004, off Reunion 
Island. The potential usefulness of maintaining coastal stations and collecting a continuous series of observations are described.

Biological processes are frequently temperaturerelated and our SST dataset is used in the study of biological responses of coral reefs and the coastal tuna fishery at Reunion Island. The coastal, and especially the coral ecosystems, are more sensitive than open-ocean ecosystems, as they are relatively shallow and currently under stress because of human population growth and coastal development. Coral bleaching is one of the major causes of worldwide reef degradation and since 1979 it has increased in intensity and frequency (Hoegh-Guldberg 1999) and understanding the processes controlling coral bleaching is a scientific priority (Sheppard 2003; Bellwood et al. 2004). Discussion of this problem shows there is an urgent need for data from different origins to be analysed at several scales and with new methods (Wooldridge \& Done 2004; Berkerlmans et al. 2004). Improving coral reef resilience is also needed as part of their long-term management in the context of threats and degradation (Obura 2005). Heat stress is considered to trigger the phenomenon on a global scale and in the South-west Indian Ocean (SWIO) several programmes are conducted regionally (see Obura 2005). A variety of data are collected to address these problems at different scales in Reunion (Conand et al. 2002; Turquet et al. 2001, 2002), which now include the decade-long temperature study presented in this paper.

Fish populations and fisheries are highly influenced by oceanographic parameters and their changes (Marsac \& Leblanc 1999; Lehodey 2001). Tuna and other top predators integrate changes affecting the whole food web (Loukos et al. 2001). The local tuna pelagic fishery during the decade is therefore also presented and analysed by the correlation of the CPUE's with SST, and the trends explored.

Long series of data are now being looked at with an increasing interest as they provide reference points to quantify the effects of global warming. The global average air temperature has increased by about $0.6^{\circ} \mathrm{C}$ during the $20^{\text {th }}$ century, and the decade of the 1990's was the warmest since the inception of records in 1861 (IPCC 2001). The International Panel for Climate Change (IPCC) forecasts a rise in global air temperature of between 1.4 to $5.8^{\circ} \mathrm{C}$ by 2100 , depended on assumptions and the model used. This paper emphasizes the need to maintain a global network of in situ observations of sea temperature for ground-truthing purposes. The trends of our decade-long series are analysed and the relevance of these local SST measurements as indicators' of large-scale phenomena is also investigated.

\section{MATERIAL AND METHODS}

\section{Temperature recorders ${ }^{1}$}

Data loggers that record temperature at a userdefined time interval were used, with the date, time and sampling interval of the loggers set by a software, through a specific interface. The loggers have autonomy of about one year, at a sampling interval of one record by hour, which has been selected for the whole period of study. From 1993 to 1996, temperatures were recorded with TEMPTIMEM ${ }^{\circledR}$ loggers, but following several technical problems, they were replaced by VEMCO MINLOG-T $\AA^{\circledR}$ loggers which were more robust. The loggers have a resolution/precision of $0.1^{\circ} \mathrm{C}$. They were calibrated in the laboratory, by comparison with a mercury thermometer. None of the readings of our loggers deviated by more than $\pm 0.1 \mathrm{C}^{\circ}$, which is similar to the accuracy of the reading on a standard laboratory thermometer. The loggers were installed on a beacon located at the entrance of the harbour of the Pointe des Galets $\left(20^{\circ} 55^{\prime} \mathrm{S}, 55^{\circ} 17^{\prime} \mathrm{E}\right)$ situated on the leeward side of the Island (fig. 1). The depth at the location of the beacon is about 10 meters and the sensor was attached along the mooring line, at 3 meters below the surface. The entrance of the harbour is open to the sea with the $100 \mathrm{~m}$ depth line occurring less than one nautical mile from the coast. Thus the sea temperature conditions reflect those of the offshore waters of the North-West of Reunion Island and those occurring on the swell breaking on Saint Gilles reef located $20 \mathrm{~km}$ southwest.

\footnotetext{
1"Note: The original data are available to the scientific community in the web www.woimsa.org. The authors will appreciate acknowledgement when the data are used."
} 


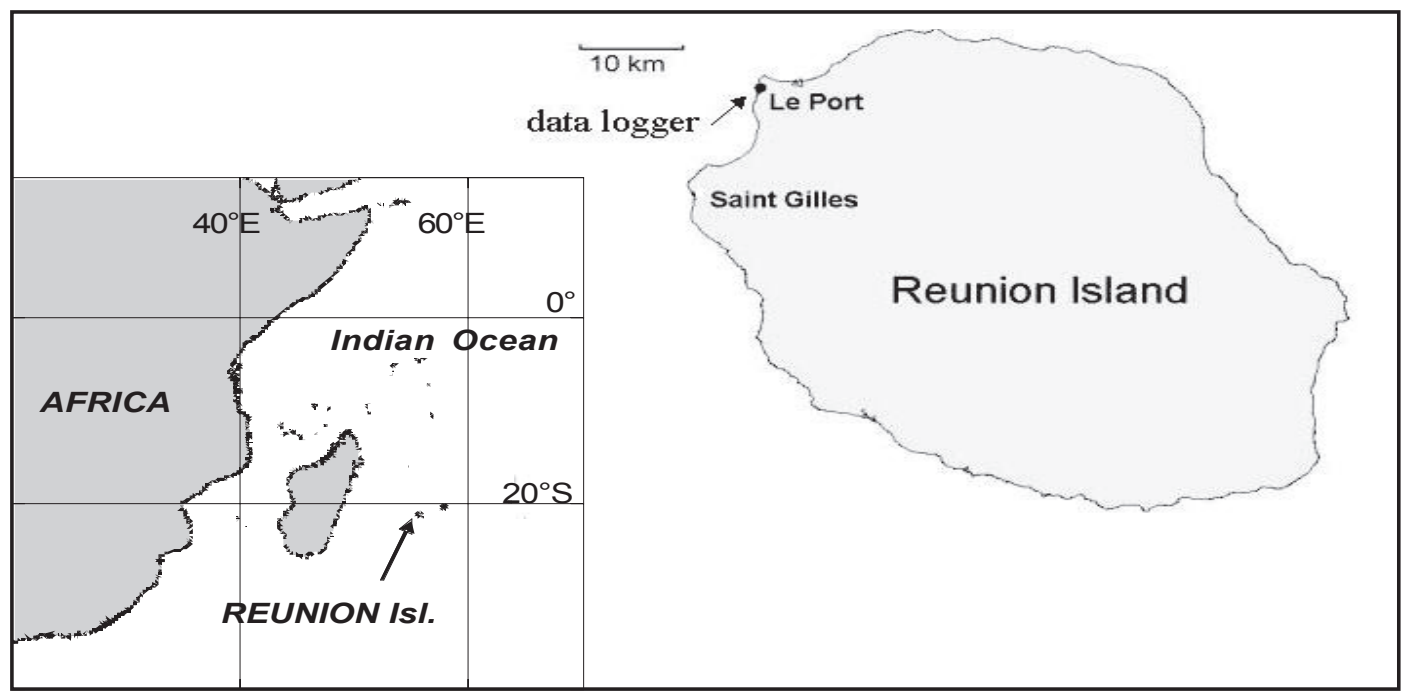

Fig. 1. Map of La Reunion, Indian Ocean, and location of the coastal station at Le Port, Pointe des Galets (black dot)

The data loggers were generally replaced every 3 to 6 months. Between July 1993 and April 1999, the series exhibits some gaps due to recording problems from various causes: abnormal power failure, abnormal temperatures, loss of the recorder and destruction of the beacon. The sensors used from 1997 onwards were more robust and a continuous series of measurements was acquired from May 1999.

The daily mean temperature (D) was established from the 24 hourly recordings. A monthly mean (M) was also calculated. For each of the 365 days of the year, a decadal daily mean $\left(\mathrm{D}_{\mathrm{d}}\right)$ was calculated over the whole period of study (July 1993-April 2004). A decadal monthly mean ( $\left.\mathrm{M}_{\mathrm{d}}\right)$ and a standardized anomaly were calculated. The standardized anomaly was obtained by dividing the raw anomaly by the standard deviation of the considered month. The deviation of $\mathrm{D}$ to $\mathrm{D}_{\mathrm{d}}$ and $M$ to $M_{d}$ were calculated for each day and for each month. A decadal annual mean $\left(\mathrm{A}_{\mathrm{d}}\right)$ is computed from the $\mathrm{M}_{\mathrm{d}}$.

\section{Auxiliary environmental data}

In order to assist in the interpretation of the SST variability and trend from our logger, other datasets concerning temperature at depth and wind stress were used. Temperature at depth was calculated from XBT (expendable bathythermograph) casts made in the area $54^{\circ} \mathrm{E}-55^{\circ} \mathrm{E} / 20^{\circ} \mathrm{S}-22^{\circ} \mathrm{S}$ extracted from the SISMER database (http://www.ifremer. fr/sismer) then integrated and processed with the GAO package (Marsac 2005). A number of 48 casts were obtained during 1972-1996 and monthly profiles were averaged from this subset. Wind stress vectors (actually pseudo wind stress vectors) were downloaded from the Florida State University web site (http://www/coaps.fsu.edu). These data are compiled from shipboard observations that are quality checked and objectively interpolated to provide a continuous data set by $1^{\circ} \times 1^{\circ}$ and month (since 1970). Data averaged from the area $54^{\circ} \mathrm{E}-$ $55^{\circ} \mathrm{E} / 20^{\circ} \mathrm{S}-22^{\circ} \mathrm{S}$ for $1993-2004$ were used. The wind stress variable used in this study is given by: $w=\sqrt{u^{2}+v^{2}}$ and expressed in $\mathrm{m}^{2} / \mathrm{s}^{2}$

\section{Biological data}

The Marine Ecology Laboratory of the University of La Reunion has obtained much information on reef ecology, management and monitoring including coral bleaching checked by yearly surveys (Conand et al. 2000; Conand 2002; Turquet et al. 2001, 2002).

Large pelagic fish such as tuna are caught in the vicinity of Reunion Island by local fishermen (Roos et al. 1996). The gears used by the artisanal fishery are the trolling line, the vertical line and short longlines. The catch statistics are collected by the Administration of Maritime Affairs from 
surveys at the landing sites of registered fishers. The production of the artisanal sector is around 1,000 metric tons/year, with large pelagic fish representing $78 \%$ of this amount. Among pelagic fish, the highest production is that of yellowfin tuna (Thunnus albacares) with a $320 \mathrm{t}$ per year catch. Two other tuna species are also considered in this study: albacore (Thunnus alalunga) and frigate tuna (Euthynnus affinis). In order to take into account the targeting strategies of the various fractions of the fleet, the catch per unit effort (CPUE) was calculated by dividing the catch of a given species by the actual number of boats targeting this species. The fleet is considered as homogeneous in terms of fishing efficiency and the fishing effort used to target a species is similar from one boat to another.

$U_{\text {smy }}=\frac{C_{\text {smy }}}{B_{\text {smy }}}$ where U denotes the CPUE, C the catch $(\mathrm{kg})$ and $\mathrm{B}$ the number of boats targeting the species $\mathrm{s}$, during the month $\mathrm{m}$ of the year $\mathrm{y}$.

A monthly average of CPUE $\left(\mathrm{U}_{\mathrm{sm}}\right)$ was calculated for the decade 1993-2003 (Table 2a):

$$
U_{s m}=\frac{\sum_{n} U_{s m y}}{n} \text { where } \mathrm{n} \text { being the number of }
$$
years $y$ in the series.
Then a standardized seasonality index (SSI) was computed on the $\mathrm{U}_{\mathrm{sm}}$ series. SSI is defined for each month as the ratio between the current month CPUE $\left(\mathrm{U}_{\mathrm{sm}}\right)$ and the maximum value of $\mathrm{U}_{\mathrm{sm}}$ found in the series. Therefore, SSI ranges from 0 to 1 . Based on the examination of the dataset and empirical knowledge of the fishery, an arbitrary threshold at 0.85 was selected to bind the peak fishing season. The peak seasons were: January-April for yellowfin, November-January for albacore and NovemberFebruary for frigate tuna. Finally, a corrected CPUE ( $\bar{U}_{s y}$ ) was calculated for each year by averaging the monthly CPUE $\left(\mathrm{U}_{\text {smy }}\right)$ during the peak seasons (for those starting in November, the value for year $y$ considers the CPUE of the last two months of the preceding year). Deviations $\left(\mathrm{D}_{\mathrm{sy}}\right)$ were calculated from the overall mean of the $\bar{U}_{s y}$ series (Table $2 \mathrm{~b}$ ):

$\bar{U}_{s y}=\frac{\sum_{m 1}^{m 2} U_{s m y}}{n}$

where $\mathrm{m} 1$ and $\mathrm{m} 2$ are the first and the last months covering the peak season, and $\mathrm{n}$ the number of months of the peak season, and

$D_{s y}=\bar{U}_{s y}-\frac{\sum_{n} \bar{U}_{s y}}{n}$ where $\mathrm{n}$ denotes the number of years in the series.

Table 1. a) SST recorded in Reunion Island from July 1993 to May 2004, with associated statistics 1a. Monthly means, decadal monthly means $\left(M_{d}\right)$, decadal annual mean $\left(A_{d}\right)$ and seasonal averages

\begin{tabular}{|c|c|c|c|c|c|c|c|c|c|c|c|c|c|}
\hline & 1993 & 1994 & 1995 & 1996 & 1997 & 1998 & 1999 & 2000 & 2001 & 2002 & 2003 & 2004 & $\mathbf{M}_{\mathrm{d}}$ \\
\hline January & & 26.9 & & 27.1 & & 27.8 & & 27.6 & 27.2 & 26.9 & 28.1 & 28.2 & 27.5 \\
\hline February & & 27.2 & & 27.8 & & 28.6 & & 27.2 & 28.2 & 27.7 & 28.5 & 28.7 & 28.0 \\
\hline March & & & & 27.6 & & 27.6 & & 27.3 & 28.4 & 27.8 & 28.6 & 28.4 & 28.0 \\
\hline April & & & & & & 27.3 & 27.0 & 26.8 & 28.1 & 27.4 & 28.0 & 27.5 & 27.4 \\
\hline May & & & 25.6 & & & 26.5 & 26.3 & 26.2 & 26.8 & 26.7 & 26.6 & & 26.4 \\
\hline June & & 25.1 & 24.8 & & 24.7 & 25.4 & 25.2 & 25.3 & 24.9 & 25.3 & 25.5 & & 25.1 \\
\hline July & 23.1 & 24.3 & 24.2 & 23.9 & 23.9 & 24.2 & 24.1 & 23.8 & 23.9 & 24.4 & 24.3 & & 24.0 \\
\hline August & 23.2 & 23.5 & 23.6 & 23.4 & 23.6 & 23.6 & 23.4 & 23.3 & 23.4 & 23.8 & 23.6 & & 23.5 \\
\hline September & 22.9 & 23.7 & 23.6 & 23.3 & 23.4 & 23.3 & 23.3 & 22.9 & 23.7 & 23.7 & 24.0 & & 23.4 \\
\hline October & 23.3 & 23.8 & 24.1 & 23.9 & 23.8 & 24.1 & 23.7 & 23.5 & 24.4 & 24.1 & 24.9 & & 24.0 \\
\hline November & 24.5 & 24.0 & 24.9 & 24.7 & 24.8 & & 25.0 & 24.7 & 25.0 & 25.2 & 25.7 & & 24.8 \\
\hline December & 25.6 & & 26.2 & & 26.3 & & 26.0 & 26.1 & 26.8 & 26.5 & 26.9 & & 26.3 \\
\hline $\mathrm{A}_{\mathrm{d}}$ & & & & & & & & & & & & & 25.7 \\
\hline Summer average & - & - & - & 27.5 & - & 27.8 & - & 27.2 & 28.0 & 27.4 & 28.3 & 28.2 & \\
\hline Winter average & 23.1 & 23.8 & 23.9 & 23.6 & 23.7 & 23.8 & 23.6 & 23.4 & 23.9 & 24.0 & 24.2 & - & \\
\hline
\end{tabular}


1. b) Monthly deviations from $M_{d}$ and mean seasonal deviations

\begin{tabular}{lcccccccccccc}
\hline & $\mathbf{1 9 9 3}$ & $\mathbf{1 9 9 4}$ & $\mathbf{1 9 9 5}$ & $\mathbf{1 9 9 6}$ & $\mathbf{1 9 9 7}$ & $\mathbf{1 9 9 8}$ & $\mathbf{1 9 9 9}$ & $\mathbf{2 0 0 0}$ & $\mathbf{2 0 0 1}$ & $\mathbf{2 0 0 2}$ & $\mathbf{2 0 0 3}$ & $\mathbf{2 0 0 4}$ \\
\hline January & & -0.6 & & -0.4 & & +0.3 & & +0.1 & -0.3 & -0.6 & +0.6 & +0.7 \\
February & & -0.8 & & -0.2 & & +0.6 & & -0.8 & +0.2 & -0.3 & +0.5 & +0.7 \\
March & & & & -0.4 & & -0.4 & & -0.7 & +0.4 & -0.2 & +0.6 & +0.4 \\
April & & & & & & -0.1 & -0.4 & -0.6 & +0.7 & 0.0 & +0.6 & +0.1 \\
May & & & -0.8 & & & +0.1 & -0.1 & -0.2 & +0.4 & +0.3 & +0.2 & \\
June & & 0.0 & -0.3 & & -0.4 & +0.3 & +0.1 & +0.2 & -0.2 & +0.2 & +0.4 & \\
July & -0.9 & +0.3 & +0.2 & -0.1 & -0.1 & +0.2 & +0.1 & -0.2 & -0.1 & +0.4 & +0.3 & \\
August & -0.3 & 0.0 & +0.1 & -0.1 & +0.1 & +0.1 & -0.1 & -0.2 & -0.1 & +0.3 & +0.1 & \\
September & -0.5 & +0.3 & +0.2 & -0.1 & 0.0 & -0.1 & -0.1 & -0.5 & +0.3 & +0.3 & +0.6 & \\
October & -0.7 & -0.2 & +0.1 & -0.1 & -0.2 & +0.1 & -0.3 & -0.5 & +0.4 & +0.1 & +0.9 & \\
November & -0.3 & -0.8 & +0.1 & -0.1 & 0.0 & & +0.2 & -0.1 & +0.2 & +0.4 & +0.9 & \\
December & -0.7 & & -0.1 & & 0.0 & & -0.3 & -0.2 & +0.5 & +0.2 & +0.6 & \\
\hline Summer average & - & - & - & -0.3 & - & +0.1 & - & -0.5 & +0.3 & -0.3 & +0.6 & +0.5 \\
Winter average & -0.6 & +0.1 & +0.1 & -0.1 & -0.1 & +0.1 & -0.1 & -0.3 & +0.1 & +0.3 & +0.5 & \\
\hline
\end{tabular}

Table 2. a) Mean monthly CPUE (in kg/boat) of the artisanal fishery by species (yellowfin, albacore, frigate tuna) and Standardized Seasonality Index (SSI). The SSI is the ratio between the mean CPUE of a given month and the maximum CPUE across the 12 mean values. The SSI greater than 0.85 (in bold) denote the peak fishing season

\begin{tabular}{lcccccc}
\hline & \multicolumn{2}{c}{ Yellowfin tuna } & \multicolumn{2}{c}{ Albacore tuna } & \multicolumn{2}{c}{ Frigate tuna } \\
& Mean & SSI & Mean & SSI & Mean & SSI \\
\hline Jan & 164.1 & $\mathbf{0 . 9 1}$ & 132.4 & 0.87 & 71.1 & $\mathbf{0 . 9 8}$ \\
Feb & 170.1 & $\mathbf{0 . 9 5}$ & 109.7 & 0.72 & 65.1 & $\mathbf{0 . 9 0}$ \\
Mar & 166.9 & $\mathbf{0 . 9 3}$ & 110.4 & 0.73 & 58.7 & 0.81 \\
Apr & 179.7 & $\mathbf{1 . 0 0}$ & 90.5 & 0.60 & 58.3 & 0.81 \\
May & 147.5 & 0.82 & 100.4 & 0.66 & 59.4 & 0.82 \\
Jun & 132.6 & 0.74 & 101.0 & 0.67 & 61.3 & 0.85 \\
Jul & 119.8 & 0.67 & 78.7 & 0.52 & 61.6 & 0.85 \\
Aug & 116.0 & 0.65 & 80.5 & 0.53 & 56.5 & 0.78 \\
Sep & 125.3 & 0.70 & 92.1 & 0.61 & 57.3 & 0.79 \\
Oct & 125.8 & 0.70 & 108.1 & 0.71 & 60.4 & 0.84 \\
Nov & 118.9 & 0.66 & 149.5 & $\mathbf{0 . 9 9}$ & 62.8 & $\mathbf{0 . 8 7}$ \\
Dec & 131.4 & 0.73 & 151.4 & $\mathbf{1 . 0 0}$ & 72.2 & $\mathbf{1 . 0 0}$ \\
\hline
\end{tabular}

\section{RESULTS}

\section{Surface Sea Temperature variability in Reunion island}

The complete data series of daily means is presented in figure 2. The series of daily mean SST, starting in July 1993 shows that the extreme temperatures recorded for the two main seasons during the last decade were $22.3^{\circ} \mathrm{C}$ on 23 July 1993 , and $29.1^{\circ} \mathrm{C}$ on 18 February 1998 and from 3 to 5 March 2004.

\section{Short term variability}

A typical example of daily variations is taken from the cold season (Fig. 3a). The lowest temperatures are observed in the early morning ( 6 to $8 \mathrm{am}$ ) and the highest in the afternoon ( 3 to $6 \mathrm{pm}$ ).

Catastrophic events like hurricanes, which occur in the austral summer, can strongly affect the daily cycle. An example is given by the strong cyclone 
2. b) Corrected CPUE and deviations by year; when a fishing season covers two consecutive years, the index for year $y$ includes the relevant months of year $y-1$ with those of the year $y$

\begin{tabular}{|c|c|c|c|c|c|c|}
\hline \multirow[t]{2}{*}{$\begin{array}{l}\text { Species } \\
\text { Fishing season }\end{array}$} & \multicolumn{2}{|c|}{$\begin{array}{l}\text { Yellowfin tuna } \\
\text { January to April }\end{array}$} & \multicolumn{2}{|c|}{$\begin{array}{c}\text { Albacore tuna } \\
\text { Nov }(y-1) \text { to Jan }(y)\end{array}$} & \multicolumn{2}{|c|}{$\begin{array}{c}\text { Frigate tuna } \\
\text { Nov }(y-1) \text { to Feb }(y)\end{array}$} \\
\hline & $\begin{array}{l}\text { Corrected } \\
\text { CPUE }\end{array}$ & $\begin{array}{c}\text { CPUE } \\
\text { deviations }\end{array}$ & $\begin{array}{l}\text { Corrected } \\
\text { CPUE }\end{array}$ & $\begin{array}{c}\text { CPUE } \\
\text { deviations }\end{array}$ & $\begin{array}{l}\text { Corrected } \\
\text { CPUE }\end{array}$ & $\begin{array}{c}\text { CPUE } \\
\text { deviations }\end{array}$ \\
\hline 1993 & 158.6 & 17.1 & & & & \\
\hline 1994 & 189.2 & 47.7 & 155.9 & 8.2 & 84.3 & 17.2 \\
\hline 1995 & 128.6 & -12.9 & 138.6 & -9.0 & 88.5 & 21.5 \\
\hline 1996 & 170.4 & 28.9 & 136.2 & -11.5 & 73.7 & 6.7 \\
\hline 1997 & 154.6 & 13.1 & 140.8 & -6.9 & 61.0 & -6.0 \\
\hline 1998 & 111.3 & $* 30.2$ & 157.2 & 9.5 & 60.3 & -6.7 \\
\hline 1999 & 133.0 & -8.5 & 110.5 & -37.2 & 55.9 & -11.1 \\
\hline 2000 & 151.4 & 9.9 & 158.9 & 11.3 & 56.8 & -10.2 \\
\hline 2001 & 119.7 & -21.8 & 195.3 & 47.6 & 69.4 & 2.4 \\
\hline 2002 & 124.2 & -17.3 & 147.7 & 0.0 & 63.4 & -3.6 \\
\hline 2003 & 115.4 & -26.1 & 135.7 & -12.0 & 57.0 & -10.1 \\
\hline Mean & 141.5 & 78.0 & 147.7 & 84.8 & 67.0 & 32.6 \\
\hline
\end{tabular}

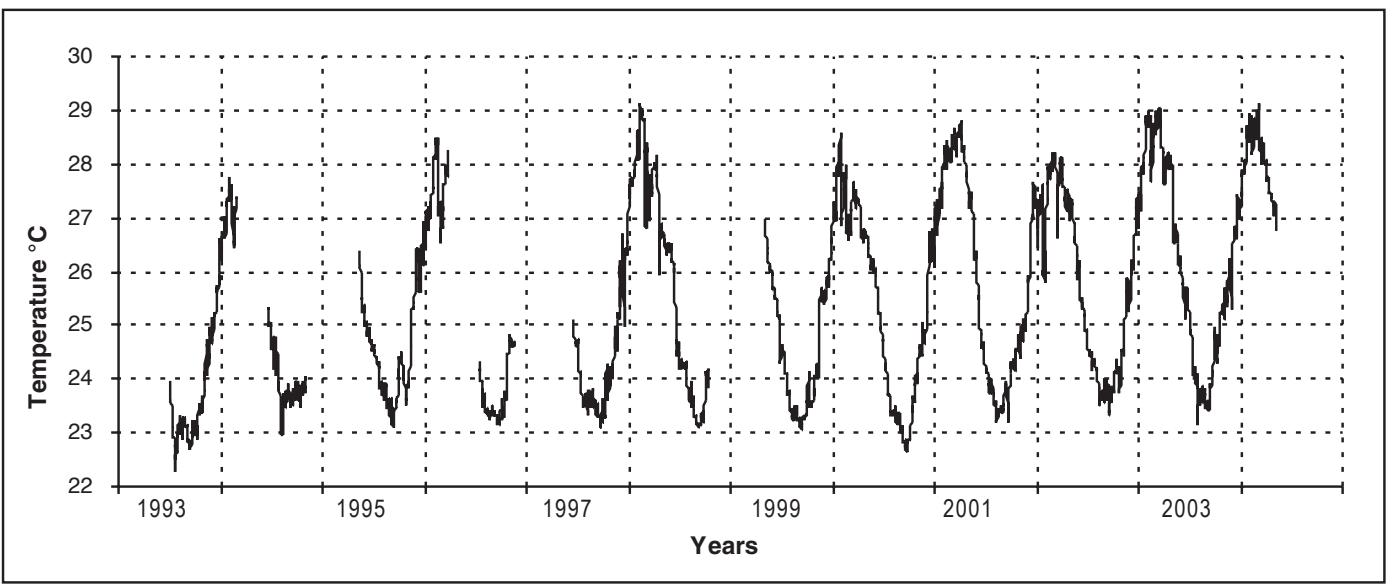

Fig. 2. Daily temperatures recorded between July 1993 and April 2004

"Dina" which passed on January $22^{\text {nd }}, 2002$ in the vicinity of Reunion Island; the shortest distance from the eye of the cyclone to our station was 30 $\mathrm{km}$ at $8.00 \mathrm{pm}$. At that time, wind gusts of $180 \mathrm{~km} / \mathrm{h}$ were recorded at Le Port with the swell generated by the wind destroying the swell recorder. A sudden drop $\left(2.4^{\circ} \mathrm{C}\right)$ of the SST was observed during this event with a cooling process lasting two days and the nearshore waters remaining cooler than normal for about nine days (Fig. 3b).
The strongest variability of daily temperatures occurs from mid-January to April, and the lowest variability in August, as depicted in figure $3 \mathrm{c}$ by the standard deviation of the daily SST.

\section{Monthly means and seasonal variability}

The $\mathrm{M}$ and $\mathrm{M}_{\mathrm{d}}$ reported in Table 1a, clearly depict the annual SST cycle on the north west coast of Reunion Island (Fig. 4). The ten-year period annual mean temperature is $25.7^{\circ} \mathrm{C}$. The two main seasons 


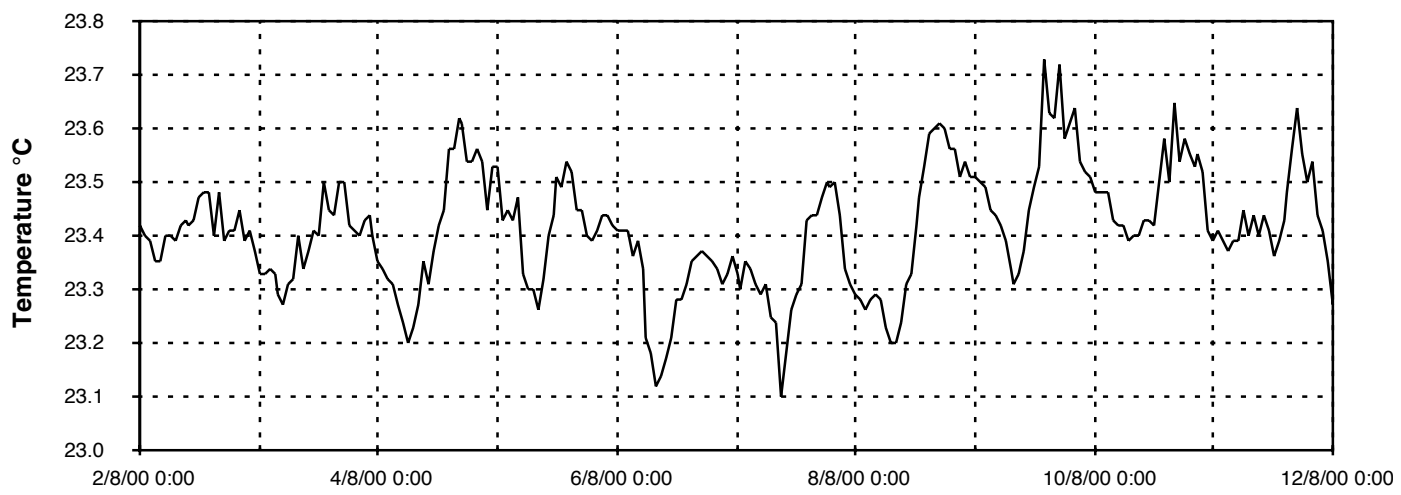

A

Date, Time

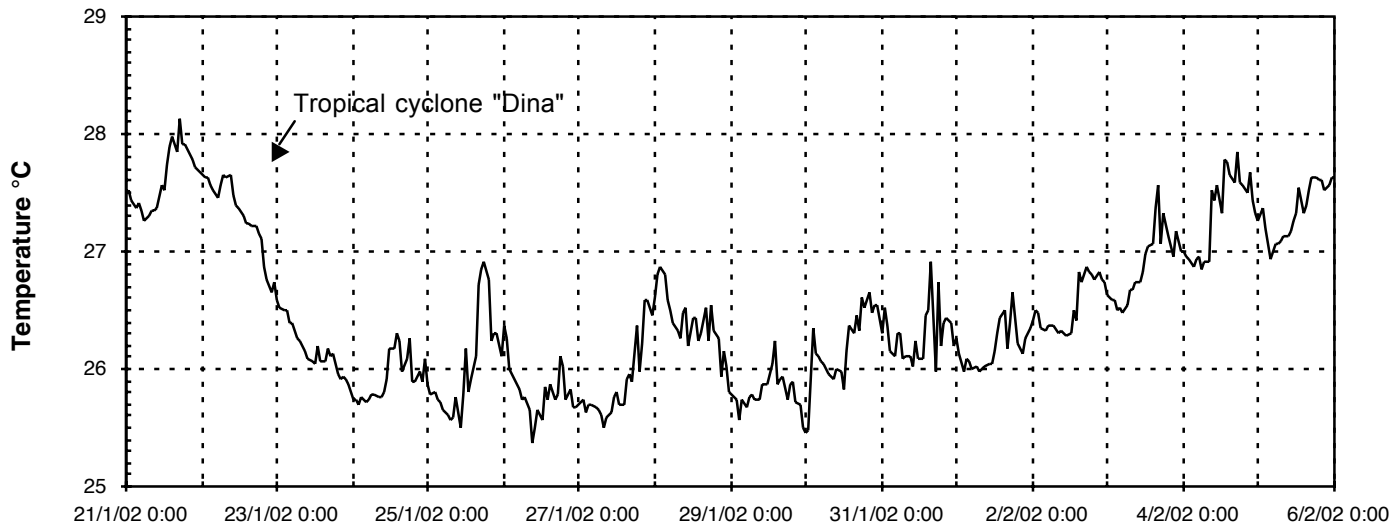

B

Date, Time

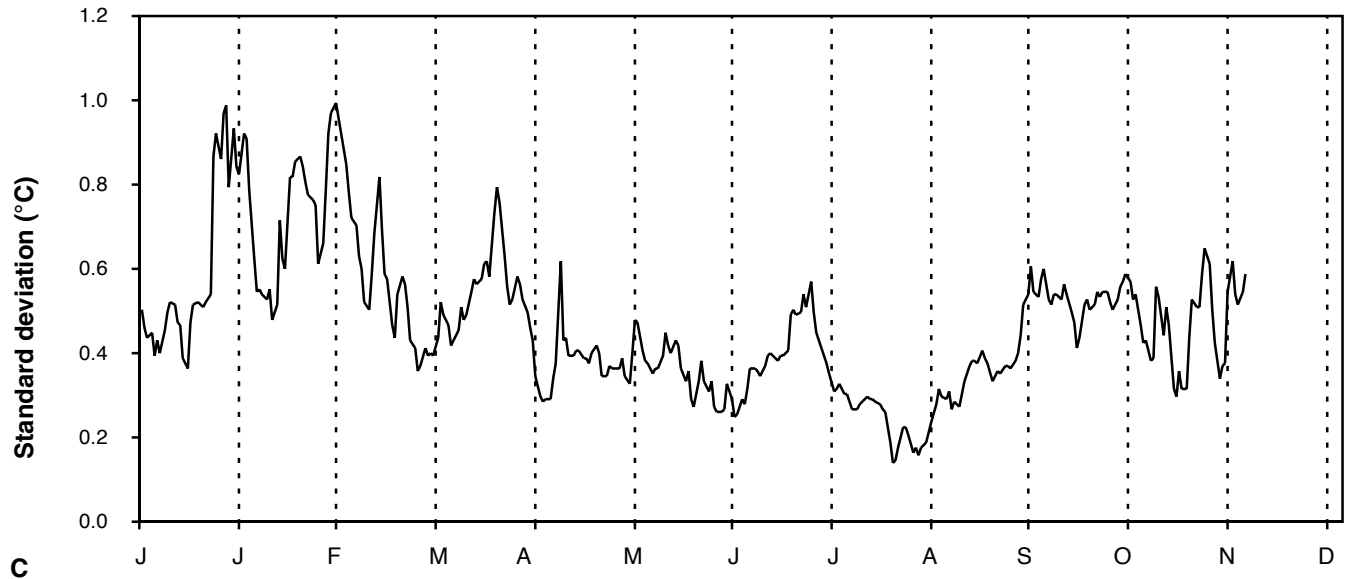

Fig. 3. Daily variations of temperature. A) A typical period during Southern winter. B) Southern summer during the cyclone Dina: nearest position from the Port at $20 \mathrm{h00}$ on January 22 ${ }^{\text {nd }}, 2004$; C) Standard deviation of the daily means of SST 


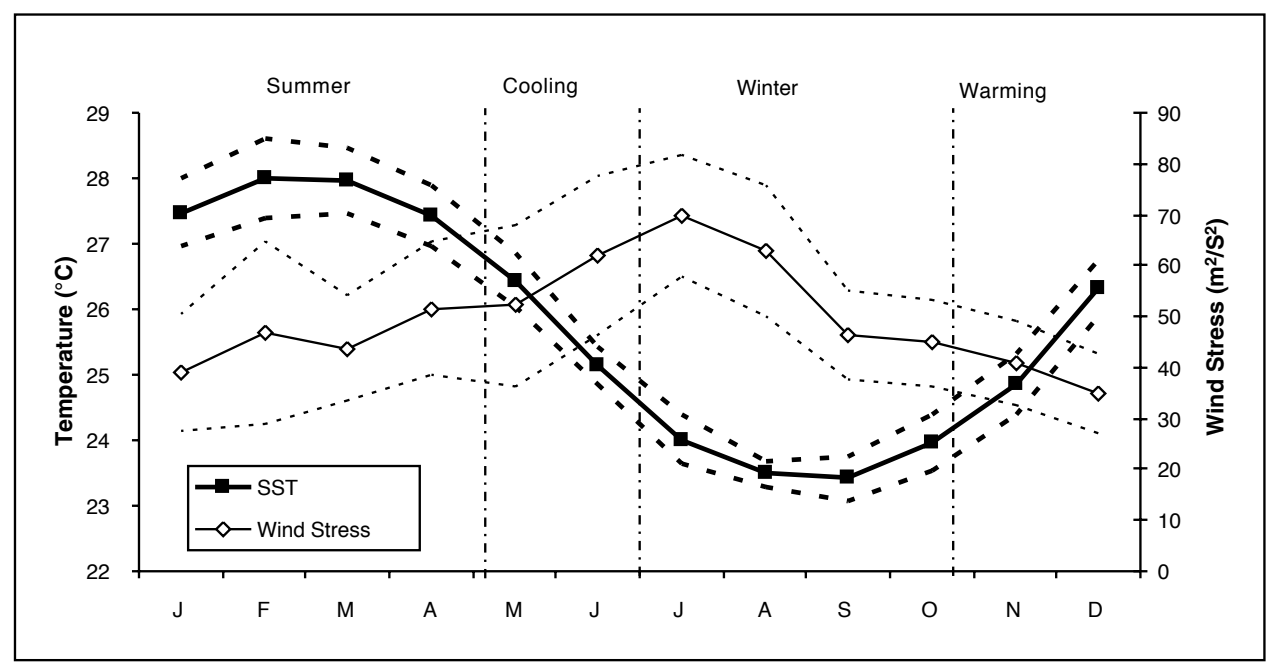

Fig. 4. Annual cycles of sea surface temperature and wind stress (from decadal monthly means) with standard deviation (dotted lines) and resulting marine seasons in Reunion island

can clearly be defined as follows: summer from January to April and winter from July to October. November/December is a transitional warming season, and May/June a transitional cooling season. The hottest months are February and March $\left(\mathrm{M}_{\mathrm{d}}\right.$ $=28.0)$ the coldest is September $\left(M_{d}=23.4\right)$. The average annual amplitude is $4.6^{\circ} \mathrm{C}$. The coefficient of variation of monthly means during the decade varies from $0.8 \%$ in August to $2.2 \%$ in February.

The annual cycle of the wind stress pattern exhibits a minimum in December-January and a maximum in July (Fig. 4). This cycle lags two months behind the SST cycle, with weaker (and stronger) wind stresses preceding the higher (and lower) temperatures. The coefficient of variation of monthly means is much greater than for SST, ranging from $17.2 \%$ in July to $38.2 \%$ in February.

The seasonal variability of subsurface temperature occurs in the first $100 \mathrm{~m}$ of the water column (data not shown, source: World Ocean Atlas 2001). During the core of the warm season (February), the mixed layer depth (MLD) is about $45 \mathrm{~m}$; it deepens to $100 \mathrm{~m}$ in winter (September). The temperature gradient in the thermocline is $1.80^{\circ} \mathrm{C} / 10 \mathrm{~m}$ in February and $0.53^{\circ} \mathrm{C} / 10 \mathrm{~m}$ in September. Below $100 \mathrm{~m}$, the temperatures at depth are similar from winter to summer, indicating no seasonal variation below the mixed layer.

\section{Trends over the ten-year period}

The deviations to the decadal daily mean, presented in figure 5 , show the periods of warmer or cooler anomalies. The largest magnitude is found during the first three months of the year. The high positive anomalies are explained by periods of calms in conjunction with higher solar insolation. The high negative anomalies occur after cyclones which induce vertical mixing in the water mass. Strong rainfall also contributes to maintain these anomalies.

The monthly deviations from $\mathrm{M}_{\mathrm{d}}$ reported in Table $1 \mathrm{~b}$ show that positive anomalies dominated since the beginning of 2001 and have remained positive since April 2002. The hottest summers occurred in 2001, 2003 and 2004. In our data series, records are missing for several summers (1994, 1995, 1997, 1999), but data from other sources (COADS) do not report any anomaly for those years. The coldest summer was in 2000 , while the warmest winters occurred in 2002 and 2003 and the coldest winters were recorded in 1993 and 2000. For all seasons there is a positive trend of temperature over the decade (Fig. 6). The average annual increase estimated from a linear fitting is $+0.088^{\circ} \mathrm{C}$ for summers and $+0.052^{\circ} \mathrm{C}$ for winters. The two transition periods were pooled as they exhibit the same slope: the average annual increase for the pooled dataset is $+0.10^{\circ} \mathrm{C}$. 

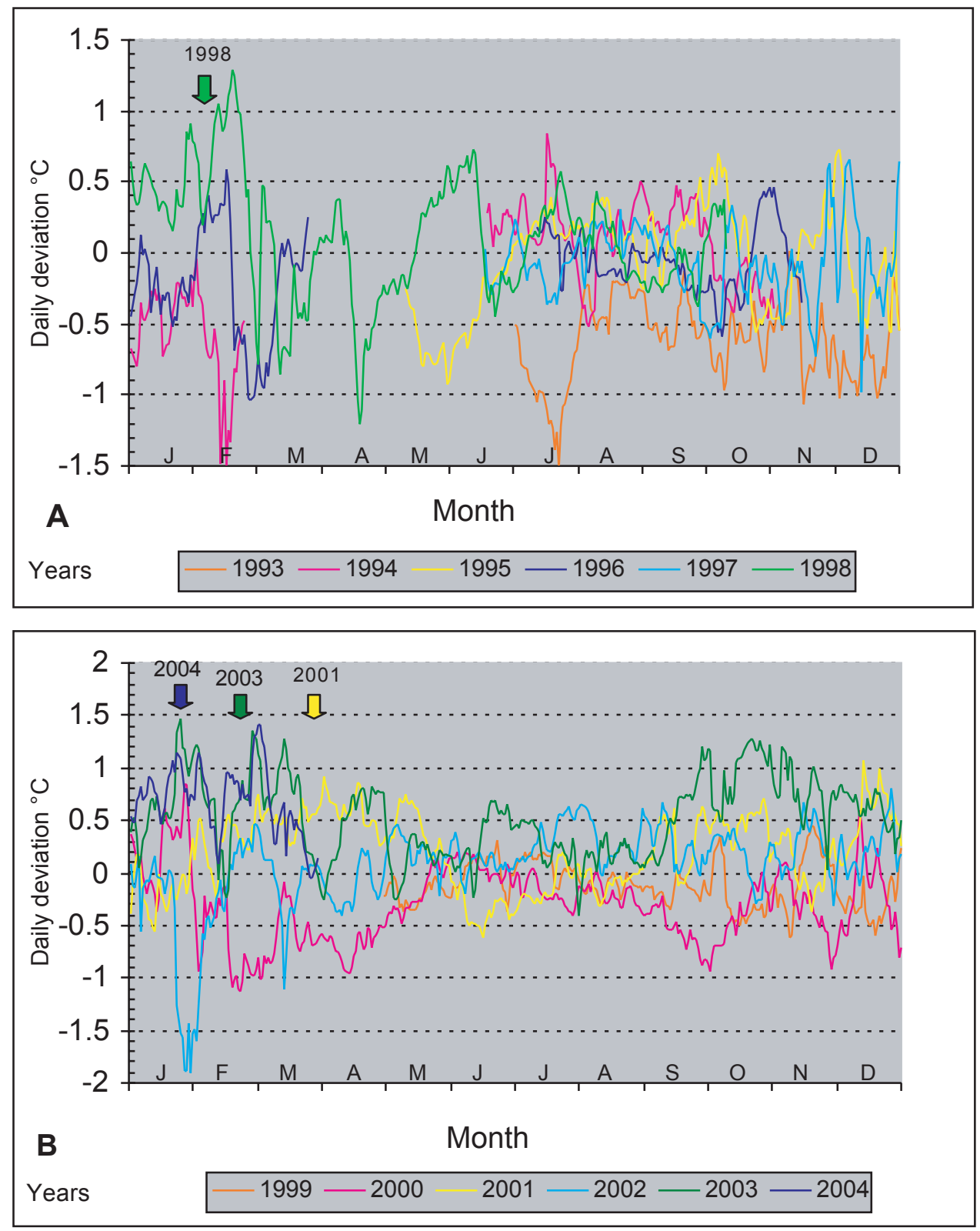

Fig. 5. Daily deviations from the decadal daily mean. A) Years 1993 to 1998 . B) Years 1999 to 2004 . The start of coral bleaching events is noted by an arrow

\section{Examples of biological responses to SST variability in Reunion island}

Bleaching. In Reunion, coral bleaching has become much more frequent during the last decade than it had been previously (Conand et al. 2002). Therefore, following qualitative observations recorded by chance, joint studies have been undertaken to better follow the onset, importance and duration of bleaching. Significant bleaching events were recorded in 1998, 2001, 2003 and 2004 (Conand et al. 2002; Turquet et al. 2001, 2002). Heat stress is the major factor of bleaching. It is clear that each event is associated with the highest temperature deviations occurring during the warm season as shown by the arrows on figure 5 . These deviations 
were particularly high in 2003 and 2004, in the range +1 to $+1.5^{\circ} \mathrm{C}$. Apart from the magnitude of the anomaly, the duration of the warming episodes is also important as shown in the cumulative plot of daily deviations $\left(\mathrm{D}-\mathrm{D}_{\mathrm{d}}\right.$ ) starting at the beginning of the warming season (November). The positive slopes denoting the lengthy warming episodes are found in January-February 1998, February-May 2001 and throughout 2003 till March 2004 (Fig.7). In 1998, the cumulative deviations grew fast until early March ( $\max$. cumulated deviations $=25.40^{\circ} \mathrm{C}$ ) then decreased rapidly until May. In 2001, the temperature rise lasted for four consecutive months and the cumulated deviations reached $26.23^{\circ} \mathrm{C}$ ). A more intense warming occurred in 2003 and 2004 with an uninterrupted warming initiated in May 2002, with the steepest slopes in the warming trend occurring during two distinct periods: January -April 2003 and October 2003 - February 2004. The start of the bleaching events are indicated by arrows in figure 7 .
Pelagic fishery. The CPUE deviations for yellowfin show a clear interannual variability that is inversely related to the local SST anomalies $(\mathrm{r}=0.81, \mathrm{p}<.005)$ (fig. 8a). There is a similar relationship for frigate tuna $(\mathrm{r}=0.80, \mathrm{p}<.005)$ (fig. 8b), but no significant relationship was found for albacore.

\section{DISCUSSION}

\section{Diurnal, seasonal cycles and decade-long trend of SST}

The diurnal variation recorded at the sampling site (Le Port) generally does not exceed $0.5^{\circ} \mathrm{C}$, which is representative of the variability of the coastal waters that are exposed to the open ocean in this part of Reunion Island. Further south along the west coast, in the lagoon and the reef ecosystem stretching over $35 \mathrm{~km}$, the SST variability has a greater

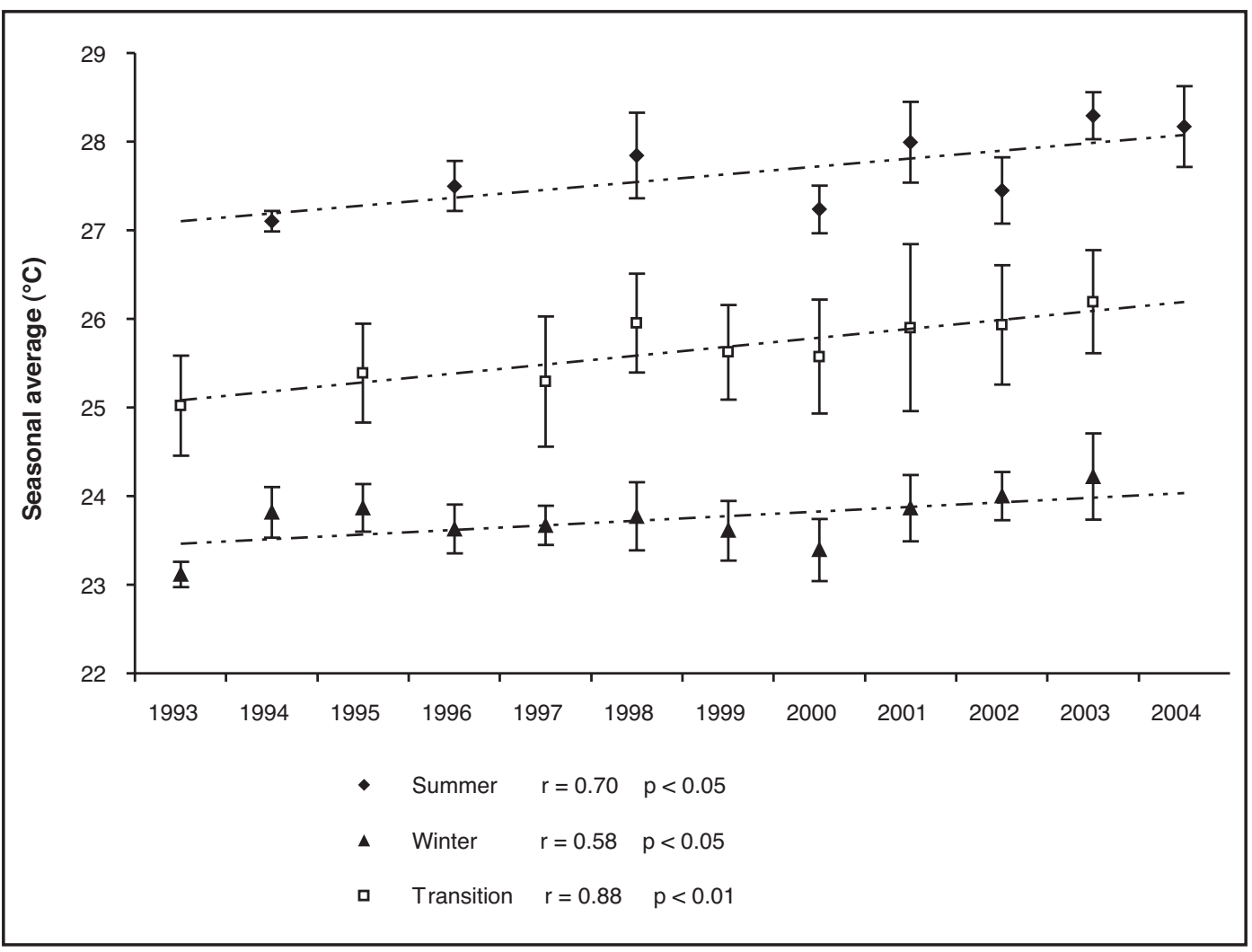

Fig. 6. Decadal trends in SST from Reunion dataset for summers and winters. The linear regressions are: Summer: Y= $0.0883 X+27.013$; Winter $: Y=0.0519 X+23.412$; Transitions: $Y=0.1012 X+24.978$ 


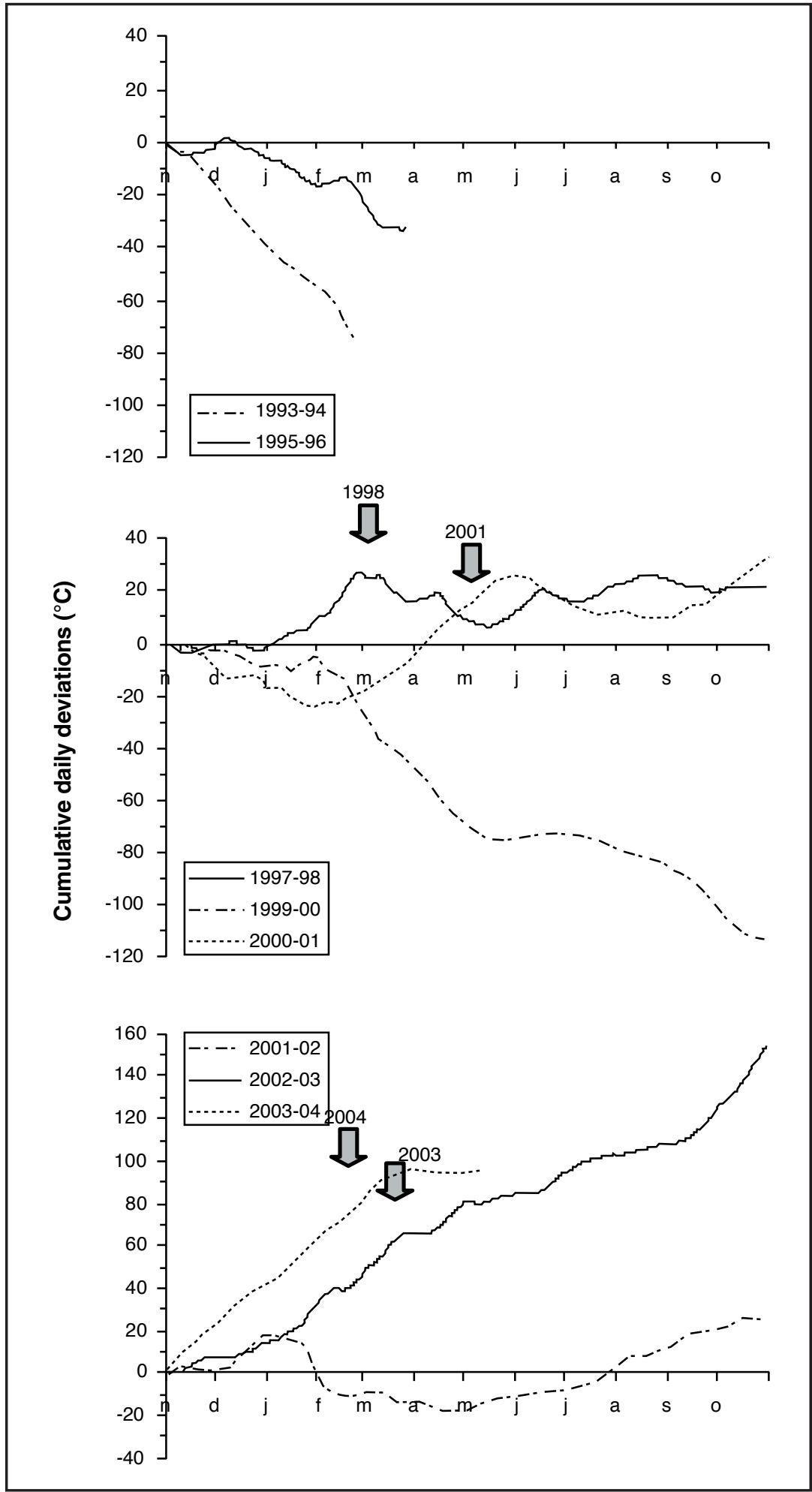

Fig. 7. Plots of cumulative daily deviations for each year. The arrows denote the coral bleaching events recorded during the period studied 
magnitude, as reported by other measurements collected during the same period of time (Turquet $e t$ al. 2001, 2002) where the mean daily temperature in summer can vary by as much as $5^{\circ} \mathrm{C}$. At night the temperature is slightly cooler in summer and colder in winter as the shallow depth in the lagoon and over the reef provides less stable conditions than in our sampling site. Despite this difference in magnitude, the diurnal pattern in the reef and lagoon area is similar to that described by the data logger, i.e. lowest (highest) temperature at 6-8 am (3-6 pm). In the short term, the high positive anomalies are explained by periods of calm in conjunction with higher solar insolation with the large negative anomalies occurring after cyclones. Strong rainfall also contributes to the maintenance of these negative anomalies.

The seasonal variability in SST is influenced by the wind stress. On an average annual cycle, SST has a lagged response of about two months behind the wind stress, with maximum (and minimum) temperature following minimum (and maximum) wind intensity. Other factors can also be invoked such as solar insolation, cloudiness and advection of cooler water masses from the southern region, but their effects were not tested because data were unavailable. Wind stress acts on the SST variability mainly by vertical mixing of the water column. In the austral summer a warm layer of about 50 meters depth develops and creates a seasonal thermocline. Sudden events like tropical cyclones can break the stratification in the water column and lower the surface temperature by mixing from deeper colder water. The warm mixed layer is formed again gradually when sea conditions become settled. Due to sustained trade winds in the austral winter the mixing process lasts longer and consequently a deeper $(100 \mathrm{~m})$ and cooler mixed layer is created. Below the winter thermocline, temperature does not vary significantly with the seasons. Such negative relationships between SST anomalies and wind forcing are known to occur at different timescales, e.g. in relation with storms (Large et al.,_1986) or at the basin scale (Wallace et al., 1990), in both tropical and mid-latitudes domains.

Over the period 1993-2004, an overall warming of the sea temperature in Reunion Island of $0.52^{\circ} \mathrm{C}$ in winter, $0.88^{\circ} \mathrm{C}$ in summer and $1^{\circ} \mathrm{C}$ during the inter-seasons is suggested by our observations. This series is only a small time window of a global oscillating system and the decade of the 1990s has been the warmest, for both air and sea temperatures. During the $20^{\text {th }}$ century, SST fluctuated at various timescales. In the tropical Atlantic, Mehta and Delworth (1995) have demonstrated the existence of quasi-oscillatory decadal $(\sim 8-20 \mathrm{yr})$ and multidecadal ( $\sim 30-50$ yrs) variability. Fluctuations at similar timescales are also evidenced from trace
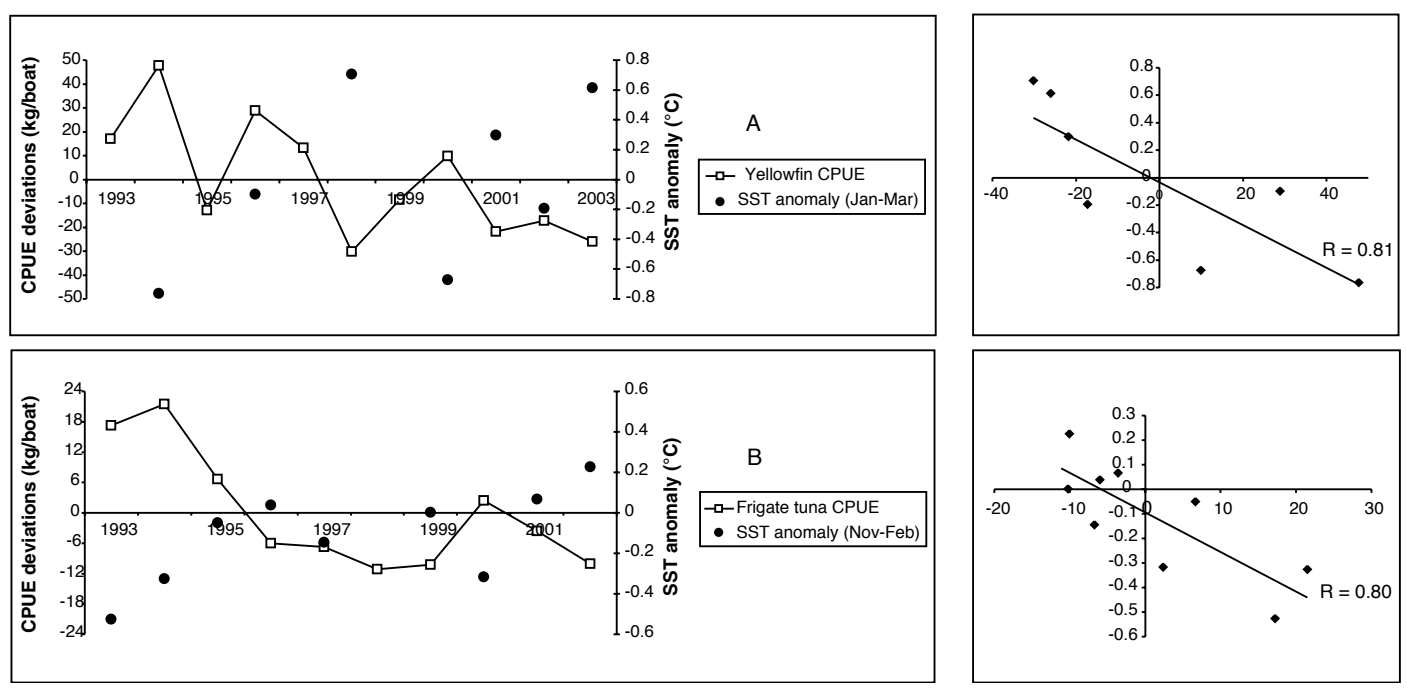

Fig. 8. CPUE deviations and SST anomalies (times series and scatterplots) during the corresponding peak fishing season for yellowfin, Thunnus albacares (A) and frigate tuna, Euthynnus affinis (B) 
elements measured in corals in the West Indian Ocean (Cole et al., 2000).

\section{Coral bleaching events}

The results of a decade of studies on bleaching in Reunion Island provide new information for these reefs from the SWIO, which have a rather small spatial scale but are patchy and variable in their characteristics (Conand et al. 2002). Among the four recorded bleaching events in Reunion Island, that of 2001 had a lesser impact (Turquet et al.. 2001); it started in April, in accordance with the late onset of the temperature rise (see Fig. 7). Conversely, the bleaching event in 2003 was well marked in the back reefs and reef flats, starting in February, when the gradient of cumulative deviations was the highest after six months of continuous temperature increase. The in situ temperature data, and its deviations, can now be used for more elaborate analyses (as suggested by Wooldridge and Done 2004). New indices based on SST with good predictive capacities (Berkelmans et al. 2004) will enable analyses of the long-term trends. These SST data are useful in setting up experiments at the appropriate periods and to interpret the biology of the organisms at individual or population levels. They will also contribute to the understanding of reef functioning, the metabolism of the different reef components and also paleoenvironments from the geochemical composition of coral skeletons combined with salinity records (Zinke et al. 2004, 2005).

\section{Local pelagic fishery}

Significant correlations are found between the CPUE deviations and the SST anomalies for yellowfin and frigate tuna, whereas no relation was found for albacore (fig. 8). Two main points can explain these results. The first one is based on surface layers exhibiting more variability than deep layers in biological enrichment. Indeed, the wind induced mixing facilitates the seeding of nutrients in the photic zone and promotes the development of a trophic chain and food supply for predators. This process concerns more specifically the upper part of the mixed layer. Conversely, a warming event will increase the stratification and will not favour enrichment in the surface layer. The second point is related to the ecology of the tuna species considered. Yellowfin and frigate tuna are surface-dwelling tunas (Cayré \& Marsac 1993) while albacore have deeper distributions (Laurs et al. 1984). Consequently, the first two species are likely to respond more clearly to anomalies in food supply in the surface layer. There are numerous examples in the literature where CPUE trends in the tropical tuna fisheries are related with environmental features at different timescales, and more specifically, sea surface temperature and mixed layer dynamics (Marsac and Hallier 1991, Lehodey et al. 1997). The vulnerability of tuna in the purse seine fishery can be assessed from the combination of physiological requirements, such as tolerance to temperature and oxygen, and regional oceanography (Sharp 1979). The industrial tuna fleets take advantage of these relationships to optimise their strategies (Le Blanc and Marsac 1999).

In our study, the decreasing trend of CPUE for yellowfin and frigate tuna as the temperature rises would suggest a negative impact of global warming on fish distribution and availability at a local scale, with worrying prospects for local economies. However, the short-time series of catch and effort available for this study does not allow determination of the long-term trend of these pelagic resources and intense fishing pressure can also play an important role in decreasing CPUE and can lead to local resource depletion. It is likely that both environment and fishing pressures effect the observed trends.

\section{Temperature trends in La Reunion and large spatial patterns}

The question arising from measurements made in a single location is 'how well do these measurements reflect the trend at large spatial scales?' To address this issue, the National Center of Environmental Prediction (NCEP) of the NOAA archive datasets were used to extract series of monthly temperature in 46 grid squares of $10^{\circ}$ longitude-latitude across the Indian Ocean. Each series was compared to the La Reunion dataset and a correlation was calculated (Pearson coefficient correlation). The geographical distribution of the coefficient is presented in figure 
9. The Bonferroni correction (Bonferroni 1936) was applied to indicate the degree of confidence of these correlations. Indeed, when several dependent or independent statistical tests are being performed simultaneously, the confidence level $(\propto)$ should be adjusted downward to consider chance capitalization. The new $\propto$ level for each comparison becomes the targeted confidence level ( 0.05 in this case) divided by the number of series tested, thus giving a $\propto$ of 0.001 . According to this rule, only six of the 46 boxes are not statistically related to the La Reunion dataset, they correspond approximately to the correlation coefficient ranging from -0.3 to 0.3 . These areas are located in the south of the Arabian Sea $\left(10^{\circ} \mathrm{N}-20^{\circ} \mathrm{N} / 50^{\circ} \mathrm{E}-80^{\circ} \mathrm{E} ; 0^{\circ}-10^{\circ} \mathrm{N} / 60^{\circ} \mathrm{E}-70^{\circ} \mathrm{E}\right)$ and in the Andaman Sea $\left(0^{\circ}-20^{\circ} \mathrm{N} / 90^{\circ} \mathrm{E}-100^{\circ} \mathrm{E}\right)$. Conversely, the highest correlations are found in the area located south of $10^{\circ} \mathrm{S}$ that covers the subtropical gyre and the Agulhas current system. This finding highlights the potential of using our SST time series as an indicator of the environmental variability in the South Tropical and Subtropical region of the Indian Ocean.

\section{CONCLUSION}

The presentation of the surface temperatures taken at a coastal station in close connection with the open sea, during the ten-year period 1993-2004, shows several points of interest. The annual cycle of sea

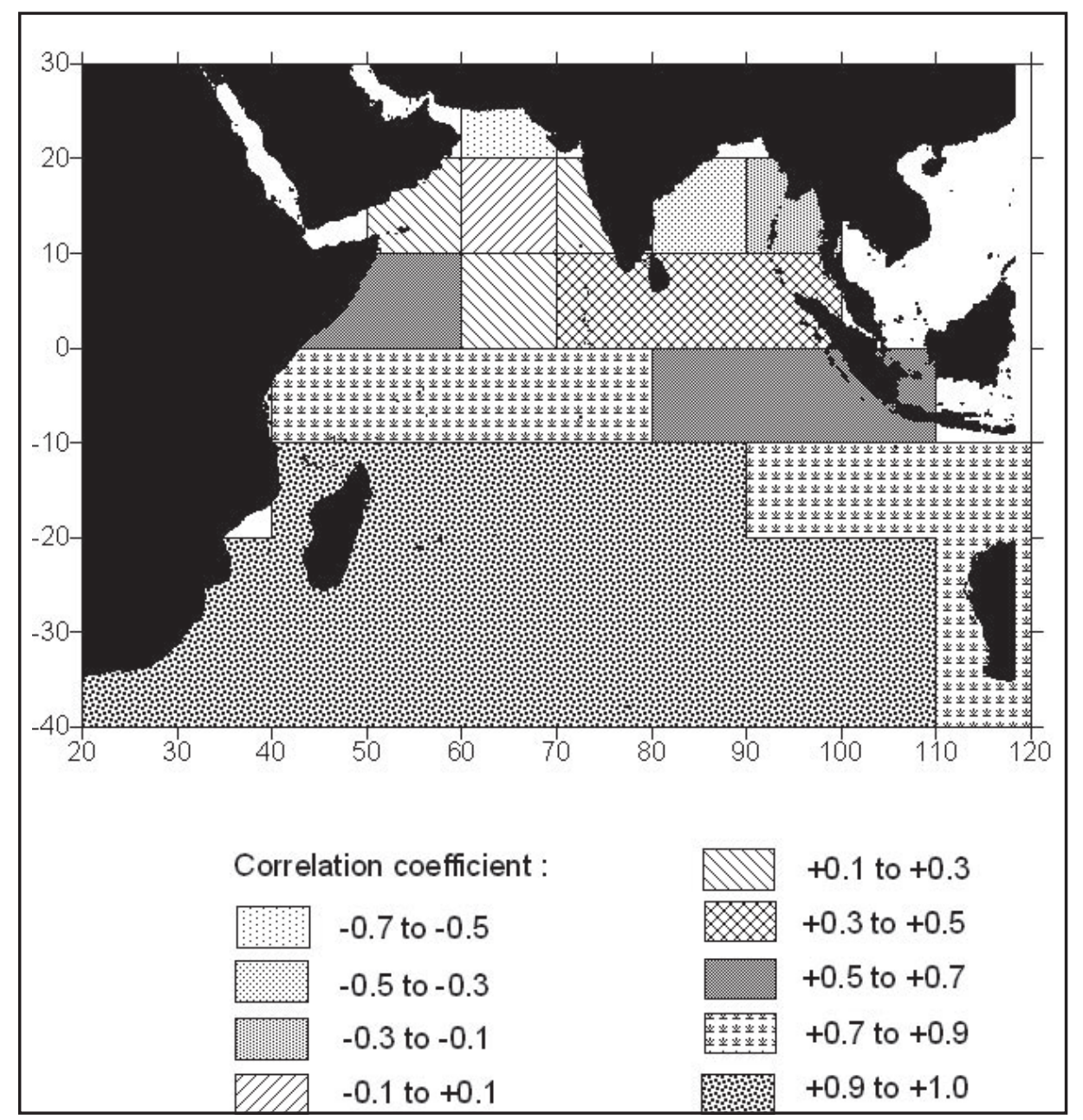

Fig. 9. Distribution of correlation coefficient between La Reunion SST series and $46 \mathrm{SST}$ series corresponding to $10^{\circ}$ grid squares across the Indian Ocean. The 0.05 significance level corresponds to correlation greater (lesser) to $0.3(-0.3)$ 
surface temperature from an undersampled region of the south tropical Indian Ocean is now described. The general trend shows warming varying from 0.52 to $0.88^{\circ} \mathrm{C}$ over the sample period. At the scale of a small island like Reunion, these simple in situ recorders are probably the most appropriate to measure changes at several temporal scales. This contribution is based on simple data treatment, and more elaborated analyses are now necessary. The Indian Ocean is covered by modelling predictions that vary greatly, leading to inconsistent predictions for the near future. In this context, and following the recommendation of the IPCC to re-activate the network of in situ observations, the coastal station located in Reunion Island can be considered as a valuable source of data.

Acknowledgments - The administration of Maritime Affairs of La Reunion is thanked for providing the catch statistics of the artisanal fishery. Drs D. Obura and J. Zinke comments have helped improve the manuscript.

\section{REFERENCES}

Bellwood, D. R., Hughes, T., Folke, C. and Nystrom M. (2004) Confronting the coral reef crisis. Nature 429: 827-833.

Berkelmans, R., De'ath G., Kinigmonth S. and Skirving, W. (2004) A comparison of the 1998 and 2002 coral bleaching events on the Great Barrier Reef: spatial correlation, patterns and predictions. Coral Reefs 23: 74-83.

Bonferroni, C. E. (1936) Teoria statistica delle classi e calcolo delle probabilità. Pubblicazioni del Istituto Superiore di Scienze Economiche e Commerciali di Firenze 8: 3-62.

Cayré, P. and Marsac, F. (1993) Modelling the yellowfin tuna vertical distribution using sonic tagging results and local environment parameters. Aquat. Living Res., 6(1): 1-14.

Cole, E. C., Dunbar R. B., McClanahan, T.R. and Muthiga, N. A. (2000) Tropical Pacific forcing of decadal SST variability in the Western Indian Ocean over the past two centuries. Science 287: 617-619.

Conand, C. (2002) Marine ecology of La Reunion: An overview of recent research. Ambio 31 (7-8): 602-605.

Conand, C., Chabanet, P., Bigot, L. and Quod J.P. (2000) Guidelines for Coral Reef Monitoring in the South-West region of the Indian Ocean. PRE/COI: 27p.

Conand, C., Larue, M., Quod, J-P., Conand, F. and Turquet, J. (2002) Bleaching in a western Indian ocean island, La Reunion: a multi-scale approach. $9^{\text {th }}$ int. Coral Reef symp. Bali, Indonésie, 23-27 oct. 2000: 1155-1160

Hoegh-Guldberg, O. (1999) Climate change, coral bleaching and the future of the world's coral reefs. Mar. Freshwat. Res. 50: 839-866.

IPCC (2001) Climate Change 2001. Third assessment report of the Intergouvernemental Panel on Climate Change IPCC (WG I and II). Cambridge Univ. Press, Cambridge.

Large, W. G., McWilliams, J. C. and Niiler, P. P (1986) Upper ocean thermal response to strong autumnal forcing of the northeast Pacific. J. Phys. Oceanogr. 16: $1524-1550$.

Laurs, R. M., Fiedler, P.C. and Montgomery, D.R. (1984) Albacore tuna catch distribution relative to environmental features observed from satellites. Deep-Sea Res., 31(9):1085-1099.

Le Blanc, J. L. and Marsac, F. (1999) Climate information and prediction services for fisheries : the case of tuna fisheries. CLIMAR 99-WMO Workshop on Advances in Marine Climatology, Vancouver, 8-15 September 1999.

Lehodey, P., Bertignac, M., Hampton, J., Lewis, A. and Picaut, J. (1997) El Nino Southern Oscillation and tuna in the Western Pacific. Nature 389: 715-718.

Lehodey, P. (2001) Modelling climate-related variability of tuna populations from a coupled ocean-biogeochemical-populations dynamics model. Fish. Oceanogr. 12 (45): 474-482.

Loukos, H., Monfray, P., Bopp, L. and Lehodey, P. (2001) Potential changes in skipjack tuna (Katsuwonus pelamis) habitat from a global warming scenario: modelling approach and preliminary results. Fish Oceanogr. 12 (45): 458-473.

Marsac F. (2005) GAO: an environmental database and software designed for fisheries biologists. Coll. Vol. Sci. Pap. ICCAT, 58 (5): 1761-1775.

Marsac, F. and Hallier, J. P. (1991) The recent drop in the yellowfin catches by the Western Indian Ocean purse seine fishery: overfishing or oceanographic changes? IPTP Coll. Vol. Work. Doc. 4: 66-83.

Marsac, F. and Le Blanc, J-L. (1999) Oceanographic changes during the 1997-1998 El Nino in the Indian ocean and their impact on the purse seine fishery. $1^{\text {st }}$ session of the IOTC working party on tropical tunas, Mahe, Seychelles, 4-8/09/99. WPTT/99/03. IOTC Proceedings 2: 147-157. 
Mehta, V. M. and Delworth, T. (1995) Decadal variability of the tropical Atlantic Ocean surface temperature in shipboard measurements and in a global ocean-atmosphere model. J. Climate 8: $172-190$.

Obura, D.O. (2005) Resilience and climate change: lessons from coral reefs and bleaching in the Western Indian Ocean. Estuarine, Coastal and Shelf Science 63: 353-372.

Roos, D., Teissier, E. and Guyomard, D. (1996) Evolution de l'activité halieutique à La Réunion de 1990 à 1996. Rapport IFREMER, 68pp.

Sharp, G. D. (1979) Areas of potentially successful exploitation of tunas in the Indian Ocean with emphasis on surface methods. Tech. Rep. IOFC/ DEV/79/47. Indian Ocean Programme, FAO, Rome

Sheppard, C. (2003) Predicted recurrences of mass coral mortality in the Indian Ocean. Nature, 425: 294-297.

Turquet, J., Mirault, E., Conand, C., Conand, F., Rard, M., Cambert, H.and Quod, J-P (2001) Réponse au phénomène de blanchissement corallien observé à La Réunion en mars-avril 2001. Rapport APMR, $35 \mathrm{p}$.
Turquet, J., Bigot, L., Cambert, H., Conand, C., Garnier, R., Mirault, E., and Quod, J-P (2002) 2001 Bleaching on Acropora dominated reefs in Reunion. In O. Linden, D. Souter, D. Wilhelmsson and D. Obura eds. CORDIO Status report 2002: 179-184.

Wallace, J. M., Smith, C. and Jiang, Q. (1990) Spatial patterns of atmosphere-ocean interaction in the northern winter. J. Climate 3: 990-998.

Wooldridge, S. and Done, T. (2004) Learning to predict large-scale coral bleaching from past events: A Bayesian approach using remotely sensed data, in-situ-data and environmental proxies. Coral Reefs 23: 96-108.

Zinke, J., Dullo, W.-Chr., Heiss, G.A. and Eisenhauer, A. 2004. ENSO and subtropical dipole variability is recorded in a coral record off southwest Madagascar for the period 1659 to 1995. Earth and Planetary Science Letters 228 (1-2), 177-197.

Zinke, J., Pfeiffer, M., Timm, O., Dullo, W. and Davies, G.R. (2005) Atmosphere-ocean dynamics in the western Indian Ocean recorded in corals. Philosophical Transactions Royal Society A 363, 121-142. 